\title{
Identifying Information Behavior in Information Search and Retrieval Through Learning Activities Using an E-learning Platform Case: Interamerican School of Library and Information Science at the University of Antioquia (Medellín-Colombia)
}

By Alejandro Uribe Tirado and Wilson Castaño Muñoz

\begin{abstract}
:
This text presents the future of librarian education as exemplified by the Interamerican School of Library and Information Science at the University of Antioquia (Medellin-Colombia), using an online learning platformLMS (Moodle) and through different personalized and collaborative learning activities and tools that help students identify their own information search and retrieval models as well as compare, adapt and improve their own information behaviors, taking into account Information Behavior Models (Wilson, Ellis, Kuhlthau) and Information Literacy Standards (ACRL/ALA, CAUL, ANZIL) that have been established in the academic and scientific literature. This learning methodology has been applied to several academic courses since 2007 with excellent results.
\end{abstract}

\section{Introduction}

It is no surprise that the Internet is students' basic and primary source of information for various personal and school-related reasons. This has created what Williams and Rowland called the "Google Generation" [1].

Students are using the Internet for almost everything from entertainment to scholarly activities and they need different literacies and competencies to interact properly with the constantly-changing digital environment. It is impossible for any individual to keep up with the Web [2].

But the tendency of today's teens and young people is to use the Internet for entertainment purposes, performing different sorts of social media practices by sharing, creating, commenting, tagging and so forth with their peers in "Web 2.0". In many cases, teens are actively involved in what Jenkins called "participatory cultures" where there are low barriers, artistic expression and civic engagement [3].

Huijser says Web 2.0 has had a great impact on learning. He mentions that if these "technologies indeed break down the boundaries between learning spaces, work spaces and private spaces, then learning itself needs to be conceptualized as far more fluid than it has hitherto been, and as more integrated into a lifelong learning journey, rather than confined in terms of time and space"
[4]. Education should focus on lifelong strategies and strive to teach competencies and literacies beyond present-day tools, so students can switch from technology to technology easily.

There is even more evidence by other authors who outline the importance of new technologies and social media that are affecting the way students behave. These authors document the technologies' impact on how students learn and how to incorporate new literacies to interact with digital content.

These new literacies should be taught in early stages. However, in developing countries where digital divide issues affect a considerable proportion of the population, digital age literacies are typically first revealed to disadvantaged students in public universities [5].

So, public universities should teach new students how to interact in the global community, how to search, locate information, create, participate, interact, comment, upload, publish, share, cite, embed in both the educational environment and ordinary life.

In library science professions, these competencies and skills should be "a must" so Library and Information Science (LIS) students must be well prepared not only to practice, but to teach these skills to other multidisciplinary students. In LIS the most important literacy is information literacy, 
which involves different sort of skills for students to interact with information in multiple formats.

Universities responsible for LIS professionals need to make sure their students acquire the necessary skills for themselves and their future users, and these universities should also focus on pedagogies and learning designs based on technology and social media [6].

That is why Learning Management Systems (LMS), based on research, should focus on:

- Collaborative environment tools that allow students to connect with teachers anywhere

- Multimedia learning materials prepared by a few experts and used by many more

- Use of network technologies allowing student to learn anywhere, anytime

- LMS which facilitate monitoring the user's progress, the diagnosis of learner needs and problems and the adjustment of structure and flow of content and of instructional system to effectively address learning objectives and needs [7].

Other research studies have focused on the conceptual framework of Learning Design (LD). For our study, we focused on five of Koper's eight principles, summarized by Berggren in the following:

- LD must include objects, services, activities, roles and solitary/group models

- LD must support blended learning: face-toface integration as well as pure online learning

- LD must describe conditions of learning: tailoring the design to specific learners or situations

- LD must stimulate reuse: portability, arrange-ability, addition and subtraction of parts

- LD must be flexible: supporting all theories of learning, pedagogically neutral $[8,9]$.

Universities in developing countries are not well prepared for distance learning due to cultural issues so their use of LMS should be based on blended learning and the platform as a support for traditional classes. In fact, LMS desertion is a long-time major obstacle for higher education [10].

It is important that universities in developing countries adopt LD and blended learning pedagogies for all their courses, so digitally illiterate students can learn and participate more efficiently in virtual environments. Library science students can become information literate by using platforms as LMS and properly-designed content that can meet their needs in order to be more effective professionals and future teachers in this ever-changing context.

\section{Background}

Information and Communication Technologies (ICT) have been an important component of the curriculum of the Interamerican School of Library and Information Science (ISLIS) at the University of Antioquia (U of A) (Medellin-Colombia) since the establishment of the University's curriculum version No. 3 in 2000. This central role of ICT in the curriculum has been strengthened even more over the past two years with curriculum version No. 4 and the respective transition plan 2007-2009 $[11,12,13,14]$.

Within these curriculum plans, ICT manifests itself as a thematic cluster--the ICT cluster--within the administrative and academic organizational structure of the U of A. Professors are responsible for including ICT components within their specific courses or modules within courses. These courses or modules need not be directly attached to the ICT cluster, but should be closely related to the application of ICT in different theoreticalconceptual and practical aspects for information and knowledge management. This pattern reinforces the information transfer cycle, which is emphasized in LIS education within the ISLIS.

From the point of view of creating curriculum, undergraduate students must have extensive contact with technologies from the very first semester until the last, inasmuch as the goal of the ISLIS is to nurture the future professional [15]: 
- Acquire the necessary tools to interact effectively in a world with an ever-growing prevalence of information technology

- Become familiar with new technologies and open to the changes and interpretations which these demand, with the critical capacity to adopt these technologies and adapt them to the environment in which he or she is immersed

- Lead in the management of information with a future vision to decide "the five Ws" of information storage and distribution

- Be creative with adaptation and appropriation processes, with a solid understanding of information resources and technologies

- Have tools for teaching the correct use of information

- Use and identify national and international information sources and resources in different formats and media

- Design and lead training programs in management and use of information

- Organize information in accordance with principles and rules that facilitate their efficient retrieval.

It is intended that postgraduate students become "highly qualified in management of information services and resources, with a systematic approach and an ability to apply the latest technologies..." [15].

In order for ISLIS students to obtain these abilities the ISLIS has developed a set of strategies with the following objectives [15] :

- Ensure the development and implementation of new educational technologies and information with a focus on allowing students not only higher efficiency and effectiveness in academic and administrative processes, but also provision of better learning opportunities, and incorporating them into curriculum development

- Provide virtual and blended learning as a mechanism to increase coverage, create a regional presence, and appropriate new information and communication technologies [ICT].

From this perspective the ISLIS has decided to focus on both ICT teaching-learning (educational process) and mediation of educational processes through virtual environments, because the informational-technological skills are as necessary as the learning-technology skills for the information professional. This relationship has been stated in institutional documents such as Competencies for Special Librarians of the 21st Century-Special Library Association, ${ }^{1}$ Competencias y Aptitudes de los Profesionales Europeos de Informacion y Documentacion-EURO-REFERENCIAL, ${ }^{2}$ Evaluación del Diseño del Título de Grado en Información y Documentación, ${ }^{3}$ European Curriculum Reflections on Library and Information Science Education, ${ }^{4}$ and by different authors in LIS [16, $17,18,19,20]$.

\section{ICT - ISLIS Courses}

In the last few years the $U$ of A utilized technologies to support the ICT cluster, including the open-source online learning platform Moodle (http://moodle.org/), to provide a virtual learning environment. Fourteen courses have been developed and one is currently under development. These courses have been designed using blended learning, and are distributed as follows in curriculum versions (cv) No. 3 and/or No. 4:

\section{Undergraduate}

- ICT systems (cv No. 3) / Computing and ICT (cv No. 4)

- Effective Internet Searching (cv No.4)

- Bibliographic Information Computerized Systems (cv No. 3) / Databases (cv No.4)

- Digital Information Services (cv No. 3 and 4)

- Web Portals Design Seminar (cv No. 3)/ Content Management (cv No.4)

- Technology Management (cv No.3 and 4)

- Specialized Information Searches (cv No.3 and 4)

- Digital Libraries Seminar (in a trial version, cv No.4) 


\section{Continuing Education}

- Seminar-Workshop: Information Architecture and Metadata Schema for Libraries

- Diploma: University Libraries (two modules: 1) User Education and Information Literacy, and 2) From Traditional to Digital Services)

- Seminar-Workshop: Search and Information Retrieval--COMFAMA, 2010 (the ICT cluster was used to train 200 library employees of COMFAMA with relation to information retrieval and information literacy).

\section{Postgraduate}

- Applied computation - Digital Information Technologies (two integrated courses/modules)

The ICT cluster also supports individual modules in other courses from different clusters, where they share similar topics related to technology. Some examples are the courses: Information Systems II (second or third semester, which supports a module on information sources, search and retrieval), and a Knowledge Management seminar (fifth or sixth semester, which supports a module on technology tools for knowledge management, data mining), etc.

\section{General Guidelines for Courses}

ISLIS ICT cluster courses are hosted on the central server of the educational platform at the $U$ of A, called Learn Online (http://aprendeenlinea.udea.edu.co), which is managed by the Vice-Rector of Teaching, through the Technology Integration Program using Moodle.

In addition to this Learn Online platform operated by the Vice-Rector, the Library System of the U of A (part of the ICT cluster) also uses Moodle to support users and provide library training programs related to information literacy. (http://formacionbiblioteca.udea.edu.co/moodle/).

All courses allow guest access to general content, but guests cannot use the tools or participate in the learning activities. ${ }^{5}$ In terms of design and minimum contents common to all university courses using this platform, instructional designers must adhere to some very general guidelines, which consist of:

- Course presentation: Every course must have a zero (0) unit which displays the following components:

o Introduction: Brief description of the course which summarizes its importance

o Methodology: How each course will ensure student learning

o Assessment: Shows all graded activities, with dates, percentages, and specific calendar weeks

o Objectives: Set for each thematic unit, which mention the achievements and the skills the student will have when the course is completed

o Content: The student can see all course content

o Bibliography: Both the course as a whole as well as each thematic unit have additional and mandatory readings for the students to reinforce their knowledge

All thematic units of ICT cluster courses follow similar structures in which the topic is introduced in a document within the platform or through external links to downloadable files that explain the theoretical framework of the unit.

In addition to these documents, the units also include a list of previous readings, which are chosen to enhance knowledge and provide more information to the student. These previous readings are in different formats, such as Word, Excel, PDF, PowerPoint presentations, and links to pages, videos and related external documents in compressed files. Similarly, each course begins with a Previous Knowledge and Experience activity, a key aspect from a teaching-learning (educational process) perspective within the ICT cluster. 
Fig.1. General structure at the beginning of the courses

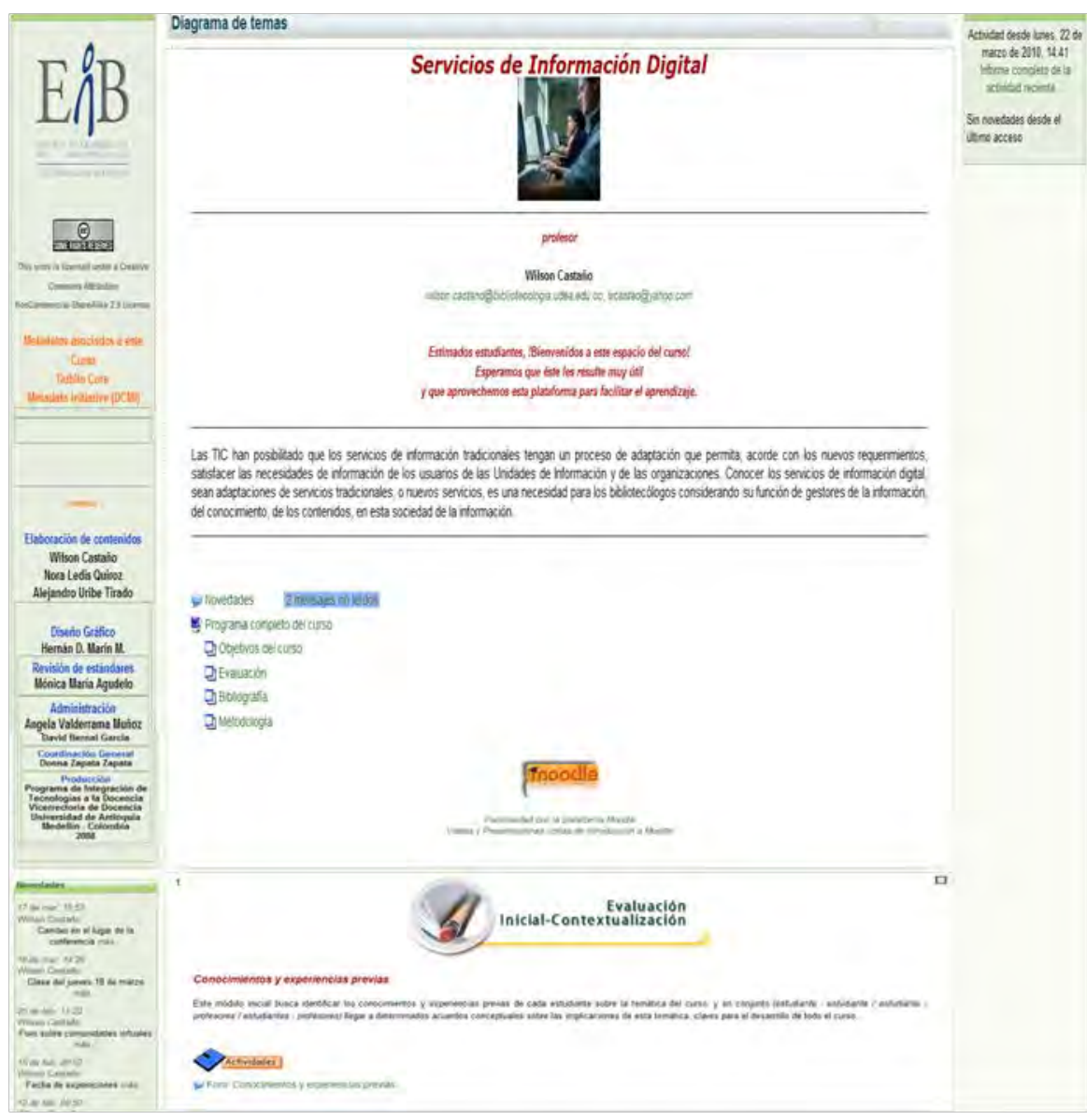

\section{Moodle platform tools as used in courses}

Among the most common tools used for courses that support the structure and instructional design are the following:

- Forum: Some forums are used simply to allow students to share experiences. Others are included in student evaluation. This collaborative tool allows teachers to respond to student queries in a way that all enrolled students can see the question and response as well.

- Workshops: Students can submit homework and other assignments through file uploads, minimizing the use of email and avoiding the associated problems.

- Course Evaluation: All courses in the ICT cluster include a self-evaluation or feedback component, where students evaluate the role of the platform within their learning process.

- Alert: All courses are programmed to send automatic information to all students via email as soon as a task, message, or assessment is available.

- Embedded: Other increasingly useful tools in the content of the course materials are the embedded elements. Thanks to HTML, XML, and mashups, students can do collaborative work using the same tool and check for updates in real time without leaving the system. 
Table 1 presents in detail the course contents and tools which are related directly or indirectly to information search and retrieval.

\section{Table 1. Curriculum courses of ICT cluster - ISLIS under the Moodle platform}

\begin{tabular}{|c|c|c|c|c|}
\hline NAME & SEMESTER & CONTENT & FILE TYPES & $\begin{array}{l}\text { METHODOLOGICAL } \\
\text { INSTRUMENTS }\end{array}$ \\
\hline $\begin{array}{l}\text { ICT systems (cv No. 3) } \\
\text { / Computing and ICT } \\
\text { (cv No. 4) }\end{array}$ & 2 or 3 & $\begin{array}{l}\text { Basic knowledge about bibliographic databases. } \\
\text {-Structure of database. -International databases for searching and } \\
\text { retrieving information.- Internet and its services }\end{array}$ & $\begin{array}{l}\text {-PDF -HTML - } \\
\text { JPG - File Folder }\end{array}$ & $\begin{array}{l}\text {-Questionnaire } \\
\text {-Forum } \\
\text {-Blog } \\
\text {-Concept maps }\end{array}$ \\
\hline $\begin{array}{l}\text { Effective Internet } \\
\text { Searching (cv No. 4) }\end{array}$ & 3 to 5 & $\begin{array}{l}\text { - Information sources - Semantic Web - Search Strategies - Search } \\
\text { Engines - Metasearch engines - Other visible sources- invisible } \\
\text { Web - Website evaluation }\end{array}$ & $\begin{array}{l}\text {-PDF -HTML - } \\
\text { Video - File } \\
\text { Folder -Power } \\
\text { Point -Word -JPG } \\
\text { - Embedded } \\
\text { elements }\end{array}$ & $\begin{array}{l}\text {-Forum -Task -Workshop } \\
\text {-Quiz } \\
\text {-Course assessment survey } \\
\text {-Embedding HTML text } \\
\text { for display embedded } \\
\text { content }\end{array}$ \\
\hline $\begin{array}{l}\text { Bibliographic } \\
\text { Computer } \\
\text { Information Systems } \\
\text { (cv No. 3) / } \\
\text { Databases (cv No.4) }\end{array}$ & 4 or 5 & $\begin{array}{l}\text { Software engineering - Databases (BD) - Software evaluation - } \\
\text { Automation }\end{array}$ & $\begin{array}{l}\text {-PDF -HTML - } \\
\text { File .exe - } \\
\text { Embedded } \\
\text { elements }\end{array}$ & $\begin{array}{l}\text {-Task } \\
\text { - Course assessment } \\
\text { survey }\end{array}$ \\
\hline $\begin{array}{l}\text { Digital Information } \\
\text { Services } \\
\text { (cv No. } 3 \text { and } 4 \text { ) }\end{array}$ & 5 or 6 & $\begin{array}{l}\text { - What are digital information services? -Features of users of } \\
\text { digital information -features of digital information services - } \\
\text { Digital information services prospective -Best practices -Creating } \\
\text { a guide for digital information services }\end{array}$ & $\begin{array}{l}\text {-PDF -Power } \\
\text { Point -Video - } \\
\text { HTML -JPG - } \\
\text { Embedded } \\
\text { elements }\end{array}$ & $\begin{array}{l}\text {-Forum -Task -Workshop } \\
\text {-Quiz } \\
\text {-Course assessment survey } \\
\text {-Embedding HTML text } \\
\text { for display embedded } \\
\text { content }\end{array}$ \\
\hline $\begin{array}{l}\text { Web Portals Seminar } \\
\text { (cv No. 3) / } \\
\text { Content Management } \\
\text { (cv No. 4) }\end{array}$ & 5 or 6 & $\begin{array}{l}\text { Conceptual Differentiation: portals, search engines, directories, } \\
\text { websites -Related key concepts: usability, navigability, } \\
\text { accessibility, information architecture, content management, } \\
\text { personalization -Library themes: organization of information- } \\
\text { knowledge (metadata) information services - Portal Trends: } \\
\text { Present and Future of Internet portals } \\
\text {-Types of portals and models needs-centered, requirements and } \\
\text { potentialities -Library Portal -Virtual communities and portals as } \\
\text { scenarios for the information and knowledge diffusion } \\
\text { - What is content management? -Elements of a content } \\
\text { management system. -Computer applications for content } \\
\text { management. -Network narratives }\end{array}$ & $\begin{array}{l}\text {-PDF -HTML - } \\
\text { JPG - File Folder }\end{array}$ & $\begin{array}{l}\text {-Forum -Task -Workshop } \\
\text {-Quiz -Readings informs } \\
\text {-Course assessment survey }\end{array}$ \\
\hline $\begin{array}{l}\text { Technology } \\
\text { Management (cv No. } 3 \\
\text { and 4) }\end{array}$ & 6 or 7 & $\begin{array}{l}\text {-Technologies in library services and process -Background of } \\
\text { Technology -Basic tools for technology management -Selection, } \\
\text { evaluation and negotiation of technology -Technology } \\
\text { management cases }\end{array}$ & $\begin{array}{l}\text {-PDF -HTML - } \\
\text { Video - File } \\
\text { Folder -Power } \\
\text { Point -Word - } \\
\text { Embedded } \\
\text { elements }\end{array}$ & $\begin{array}{l}\text {-Forum -Task -Workshop } \\
\text {-Quiz } \\
\text {-Course assessment survey } \\
\text {-Embedding HTML text } \\
\text { for display embedded } \\
\text { content }\end{array}$ \\
\hline $\begin{array}{l}\text { Specialized } \\
\text { Information Searches } \\
\text { (cv No. } 3 \text { and 4) }\end{array}$ & 6 to 8 & $\begin{array}{l}\text { What is information search and retrieval? Why is education in this } \\
\text { area in the field of information science important in current } \\
\text { society? What are the information search and retrieval paradigms: } \\
\text { Focus on systems and user-centered? -Information search and } \\
\text { retrieval models -Models, and Standards of Information Literacy - } \\
\text { Step and generic strategies for information search and retrieval - } \\
\text { Copyright in digital information management, Web Information } \\
\text { Sources and Evaluation of Information Sources -Practice in } \\
\text { different digital information resources }\end{array}$ & $\begin{array}{l}\text {-PDF -HTML - } \\
\text { Video - File } \\
\text { Folder -Power } \\
\text { Point -Word - } \\
\text { Embedded } \\
\text { elements }\end{array}$ & $\begin{array}{l}\text {-Forum -Task -Workshop } \\
\text {-Quiz } \\
\text {-Course assessment survey } \\
\text {-Embedding HTML text } \\
\text { for display embedded } \\
\text { content }\end{array}$ \\
\hline $\begin{array}{l}\text { Seminar-Workshop: } \\
\text { Information } \\
\text { Architecture and } \\
\text { Metadata Schema for } \\
\text { Libraries-Information } \\
\text { Units }\end{array}$ & $\begin{array}{l}\text { Continuing } \\
\text { Education }\end{array}$ & $\begin{array}{l}\text { Internet-wide context for information architecture and metadata } \\
\text { schema. - From an Internet of service and general information to a } \\
\text { specialized Internet with information structured and quality -A } \\
\text { kind of metadata, a type of service and a type of information } \\
\text { retrieval. - The metadata, a proposal of library and information } \\
\text { science - The libraries web sites, the first space for metadata -A } \\
\text { case study -The EAFIT University Mega-library }\end{array}$ & $\begin{array}{l}\text {-PDF -Power } \\
\text { Point -HTML - } \\
\text { Word }\end{array}$ & $\begin{array}{l}\text {-Forum } \\
\text {-Course assessment survey }\end{array}$ \\
\hline
\end{tabular}




\begin{tabular}{|c|c|c|c|c|}
\hline $\begin{array}{l}\text { Diploma: } \\
\text { University Libraries } \\
2 \text { Modules: } \\
\text { User Education and } \\
\text { Information Literacy - } \\
\text { From Traditional to } \\
\text { Digital Services). }\end{array}$ & $\begin{array}{l}\text { Continuing } \\
\text { Education }\end{array}$ & $\begin{array}{l}\text {-Information Literacy (INFOLIT) Conceptualization. -Information } \\
\text { Behavior Models -Pedagogical Models and Standards of } \\
\text { Information Literacy. -INFOLIT Best practices in universities. } \\
\text {-Use of technology in university libraries. Digital Profile and Web } \\
2.0 \text {-Digital information services: importance in university } \\
\text { libraries. -Digital Libraries. -Tools for selection, evaluation and } \\
\text { negotiation of technology applied to university libraries - } \\
\text { Technology Management: Concepts and models. -Tools, } \\
\text { innovation, prospective and transfer. Intellectual property on } \\
\text { technological matters. -Tools, negotiation, acquisition and } \\
\text { deployment of technology. }\end{array}$ & $\begin{array}{l}\text {-PDF -Power } \\
\text { Point -HTML - } \\
\text { Word -Tutorials } \\
\text { Flash }\end{array}$ & $\begin{array}{l}\text {-Forum } \\
\text {-Conceptual maps } \\
\text {-Course assessment survey }\end{array}$ \\
\hline Applied computer & Postgraduate & $\begin{array}{l}\text { Conceptual agreement: Implications of ICT in today's society and } \\
\text { organizations -ICT, its impact on organizational management and } \\
\text { the opportunities and threats of information professionals - } \\
\text { Software overview, tools used for better organizational } \\
\text { management -Knowledge tools and management tools -Network- } \\
\text { management tools and proactive attitude -Marketing and process } \\
\text { tools -Training of employees }\end{array}$ & $\begin{array}{l}\text {-PDF -JPG - } \\
\text { HTML -Zip }\end{array}$ & $\begin{array}{l}\text {-Forum -Task -Workshop } \\
\text {-Course assessment survey }\end{array}$ \\
\hline $\begin{array}{l}\text { Digital information } \\
\text { technologies }\end{array}$ & Postgraduate & $\begin{array}{l}\text {-Relation: technology management and strategic planning and } \\
\text { technology -ICT productivity paradox -Planning and decision } \\
\text { making technology -Acquisition, evaluation and incorporation of } \\
\text { ICT }\end{array}$ & $\begin{array}{l}\text {-PDF -Zip - } \\
\text { HTML -video - } \\
\text { JPG -Audio - } \\
\text { Excel }\end{array}$ & $\begin{array}{l}\text {-Forum -Task -Workshop } \\
\text {-Course assessment survey }\end{array}$ \\
\hline
\end{tabular}

\section{Education in information search and retrieval}

Considering the different courses related to the ICT cluster within ISLIS and mediated by the Moodle platform, presented in general form in Table 1, we note that in several courses, information search and retrieval is a subject and a practice that has been used by students to acquire the necessary skills for better academic performance. Thinking for the future, this in turn enables them to become highly skilled information and knowledge managers and information literacy educators, because for both these activities, competencies in information search and retrieval are key issues.

From examining these courses, we find that information search and retrieval competencies are included because they are important in research education at the ISLIS. By participating in these courses, students can acquire the following competencies related to knowing, doing, and being:

In Knowing: The student...

- is aware of the importance of information in the development of modern society and organizational strategic performance;

- identifies the different types of information units and the main services that a library provides to its users;

- learns about the main concepts related to the computer world, networks, hardware and software;

- identifies the main implications of the digital world, the architecture underlying the Internet and its services and tools; and

- learns about the different applications of technology in various library processes: information management, information services and library management.

In Doing: The student...

- is able to create presentations and work with spreadsheets;

- is able to use Internet communication tools has a basic understanding of web design and effective information search and retrieval; and

- is able to design and create databases as a key element for various digital information services.

In Being: The student...

- has collaborative attitudes towards information sharing and engages in actions that facilitate teamwork, and

- identifies his/her strengths and/or weaknesses in his/her interaction with technology and his/her attitude to it as an area of learning and practical work. 
Course: Computing and ICT (second or third semester)

\section{Figure 2. Computing and ICT}

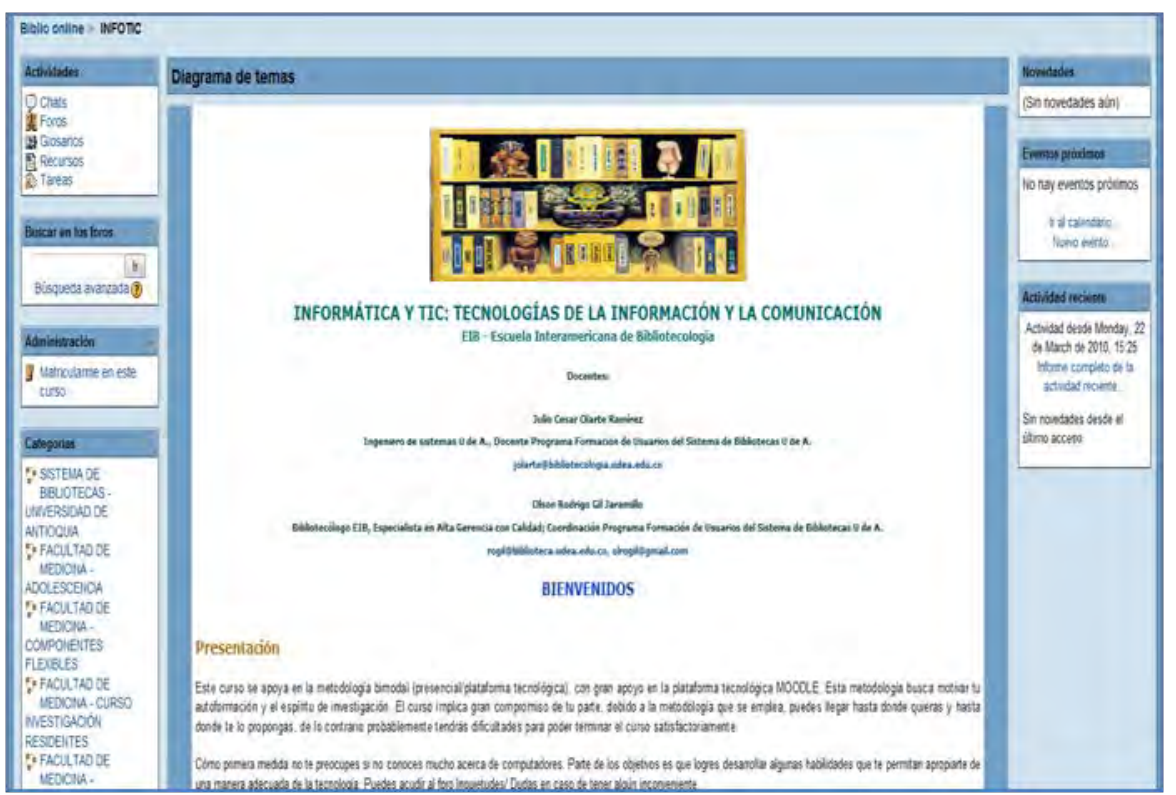

This course from curriculum version No. 4 is available in the second semester. Its objective is to introduce the technological components students will see throughout their coursework.

Modules related to information search and retrieval:

$>$ International databases for searching and retrieving information.

This module of 15 hours contains information on:

o Basic concepts about databases

o Database structure

o International databases for searching and retrieving information (EBSCO, Science Direct, Wilson, Thompson, Current Contents, OECD, ERIC, LISA)

o Legal databases (LEGIS NET, Notinet)

o Online journals (ACS, EJS, JSTOR) o Books online

The Internet and its services:

This module of 18 hours contains information on:

o Internet 2

o Deep web, deep Internet

o Domain System

o Client/server technology

o Culture and Internet safety

0 Intranet and extranet

o Communication services (e-mail, discussion forums, distribution lists)

0 Access services to information (FTP)

o Searching for information services (WWW)

o Web 2.0 applications and tools

o New browsers

o E-learning platforms 
Figure 3. Course: Computing and ICT. Module: Information search and retrieval strategies

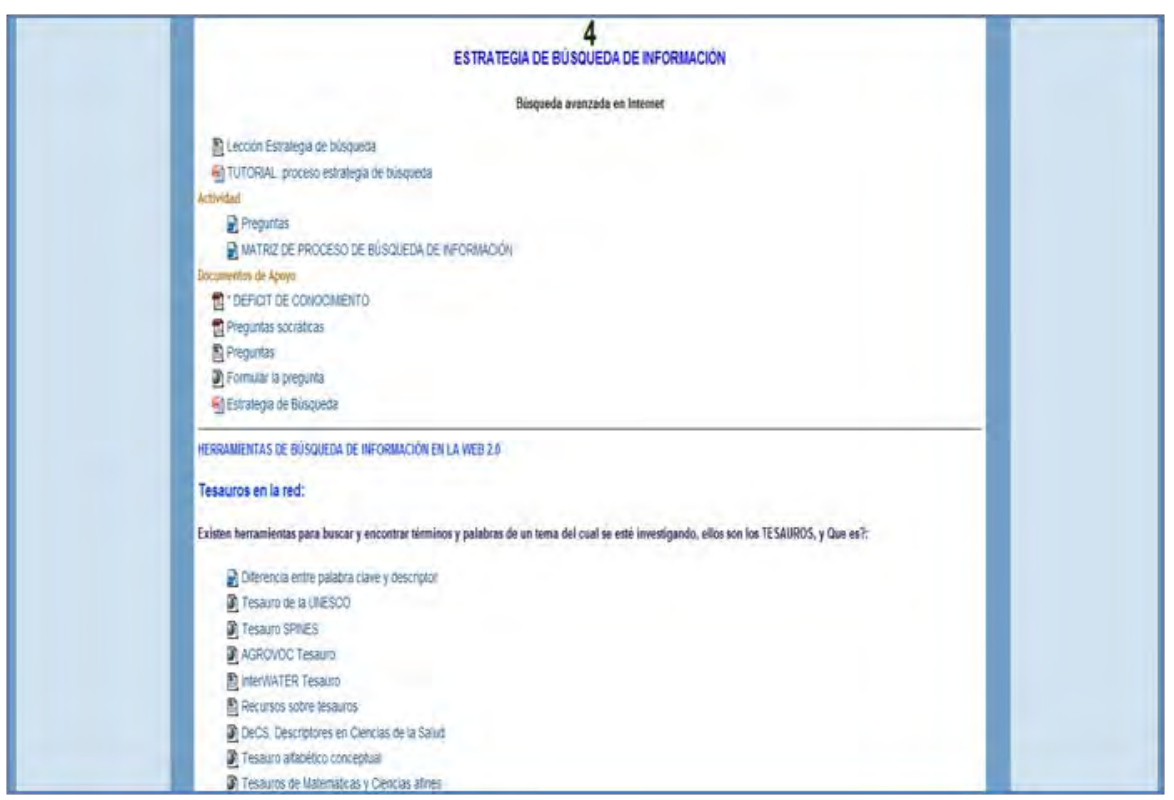

- Course: Effective Internet Searching (third to fifth semesters)

Figure 4. Effective searches on the Internet

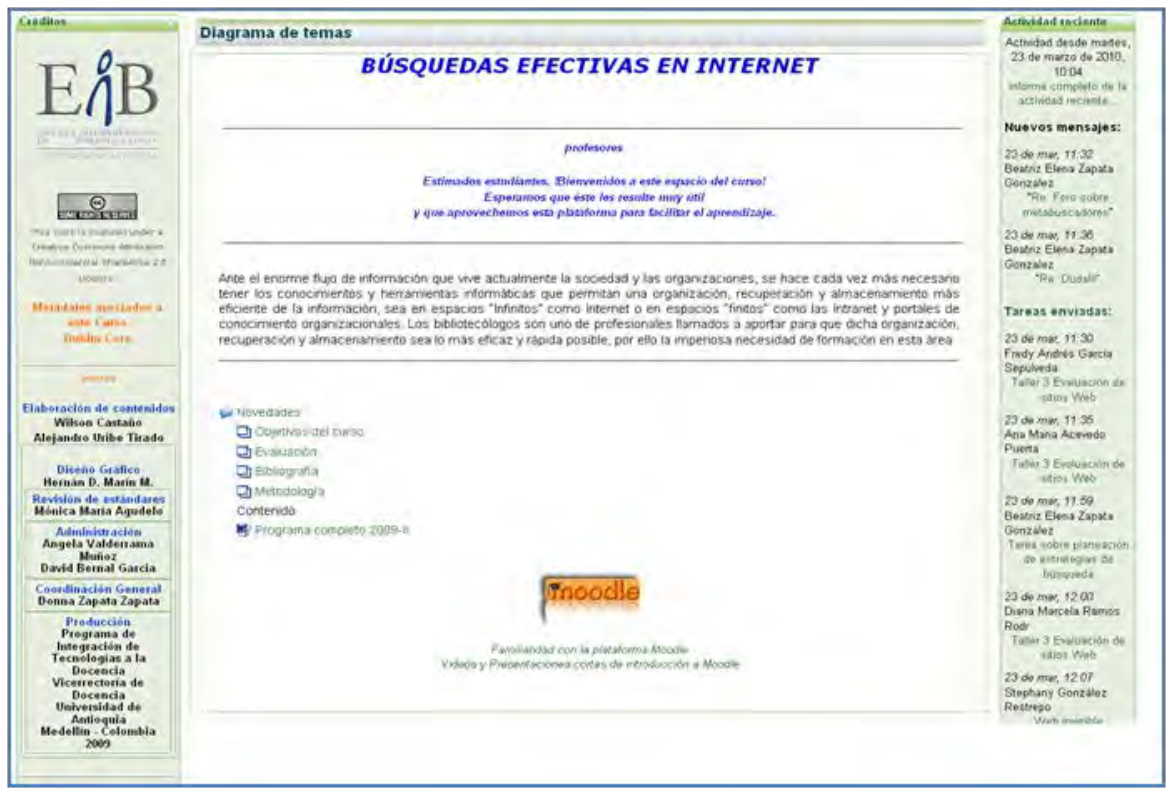

This elective course for students from both curriculum versions No. 3 and No. 4 covers 30 hours and offers the possibility for students to learn even more about how to perform effective information search and retrieval, particularly on the Internet, since, "in light of the enormous flow of information that currently arises out of our society and organizations, so is it becoming increasingly necessary to have knowledge and tools that enable an organization better and more efficient information search and retrieval, whether in 'infinite' spaces such as the Internet or 'finite' spaces such as Intranets and organizational knowledge portals" (Presentation Course).

Education Libraries, Volume 34, Number 1, Summer 2011 
This perspective implies that librarians are the professionals in charge of organizing, retrieving, and storing information as effectively and quickly as possible. The general objective of this course is that "students can learn about the different sources and the specialized and advanced strategies used for information search and retrieval on the Internet."

Some of the specific objectives are to:

- Identify the distinctive features of digital information search

- Define, for a single piece of data, its origin, current, relations between documents and their relationship to a defined area of interest

- Identify and classify information sources and resources according to the information needs to resolve

- Know the main digital information sources and resources

- Practice different strategies for digital information search and retrieval

- Assess critically the results of the digital information search and retrieval.

This course gives students who complete the program essential tools for carrying out their work activities. The curriculum also offers other courses for last semester students such as "Specialized Information Searches." Upon completion of this curriculum, the students will have the necessary tools to search and retrieve information, and when they are about to finish their coursework they can refresh their knowledge with new tools in five semesters.

General Subjects Course. (All related to the search and retrieval of information)

- Information Sources: Information types; organization of information; how information is stored

- Semantic Web

- Search Strategies: What is information search and retrieval? Includes analyzing information needs; Boolean operators; Questioning

- Search Engines: How do they work? What are the main search engines?

- Metasearch Engines: What are metasearch engines? How do they work?

- Invisible Web

- Evaluating Web sites: Criteria for evaluating Web sites

- Other sources of information: OPACs, directories, forums, databases, Google Books, Google Scholar, Open Access, Digital Libraries. 
Figure 5. Course: Effective Searches on the Internet Module: Information search strategies

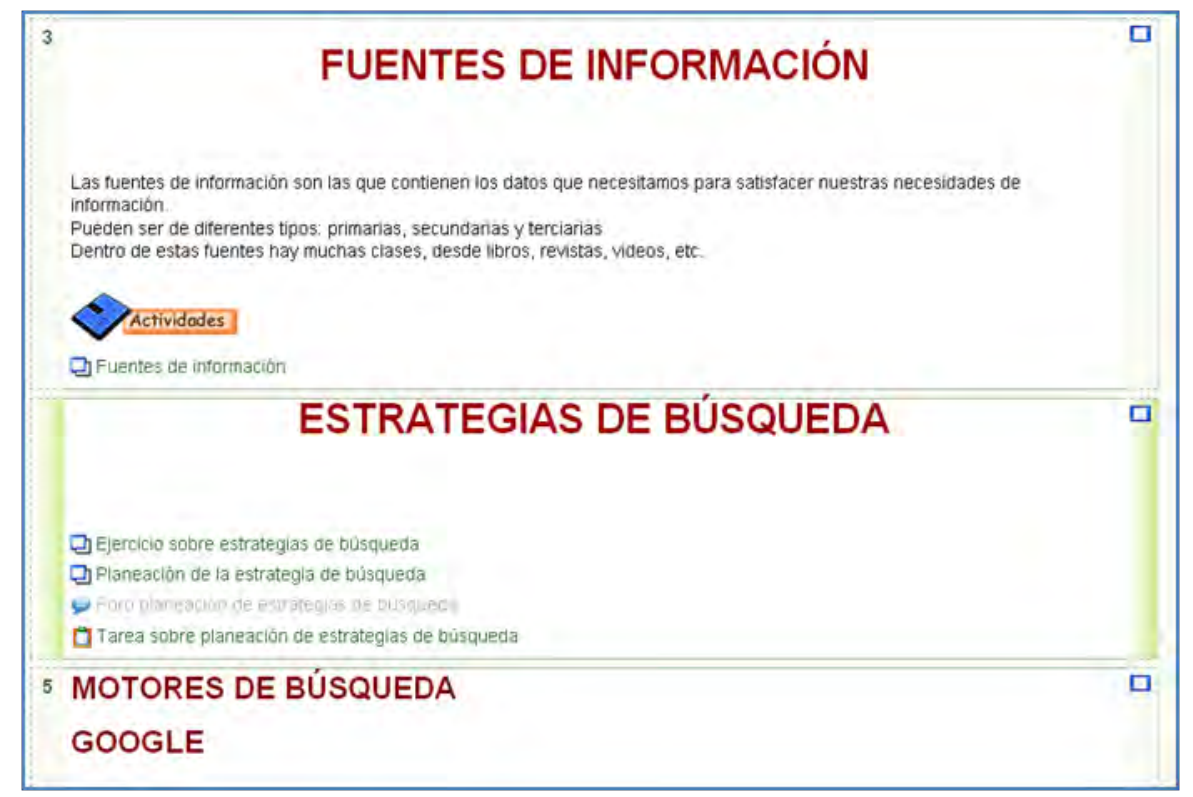

Course: Specialized Information Searches (sixth to eighth semesters)

Figure 6. Course: Specialized searches for information

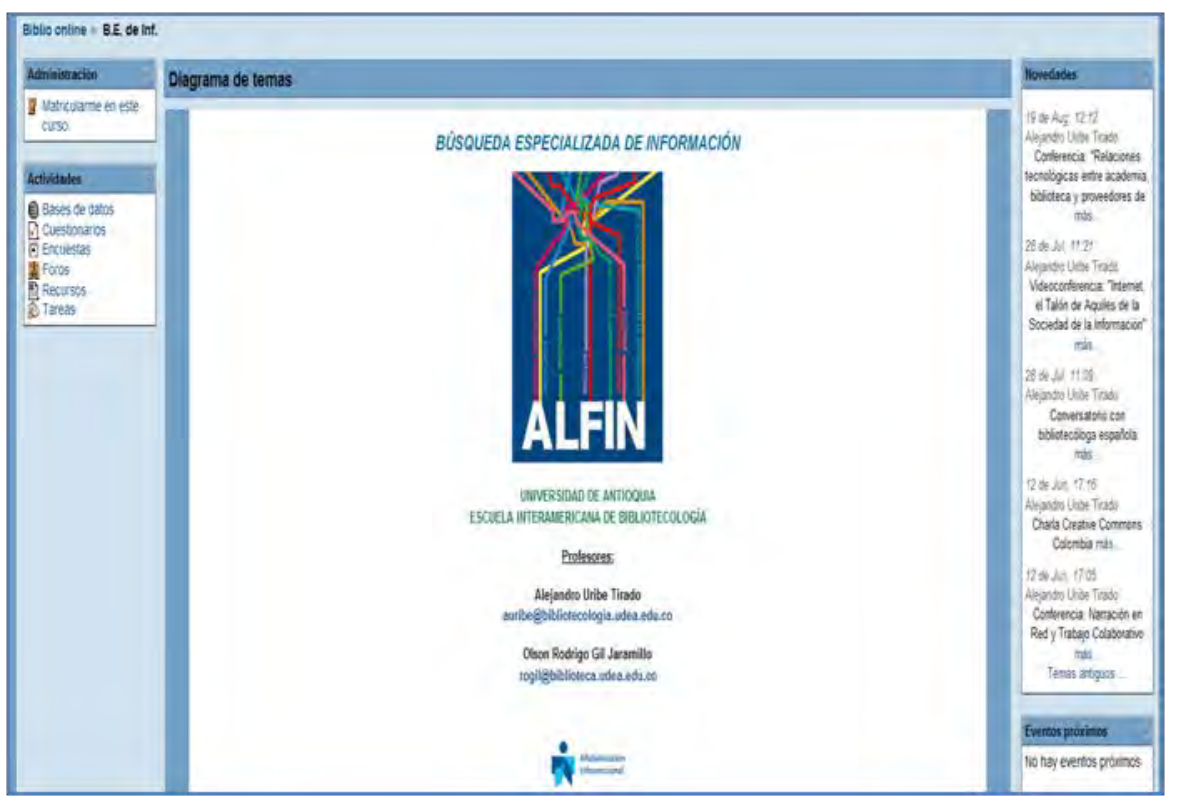

This elective course for the students' final semester is designed to bring students up-to-date about new tools and more efficient ways to search the Internet. As a 60-hour course (longer than the first elective course, "Effective Internet Searching"), it complements the search skills students have already acquired, but also provides the main components of information literacy and brings the student beyond the technical components and technologies used in a search. Rather than focus on the user and the platform, this course introduces the algorithms upon which the different search engines are built. As future information professionals, it is important that students know these search elements, as these are 
predominant factors for creating catalogs and information retrieval tools.

General Subjects Course. (All related to the search and retrieval of information)

- Theoretical-conceptual-contextual framework: What is information search and retrieval? Why is education important in this area in the field of information science in our current society? What are the information search and retrieval paradigms (Focus on systems/Usercentered approach)?

- Information search and retrieval models: Wilson, Ellis, Kuhlthau, etc. ${ }^{6}$
- Models and Standards of Information Literacy: ACRL/ALA, CAUL, ANZIL, etc. $^{7}$

- Steps and generic strategies for information search and retrieval

- Copyright in the management of digital information : Intellectual property, digital content licenses, proprietary information, Creative Commons

- Web information resources and evaluation of Web information resources

- Digital information resource practice.

Figure 7. Course: Specialized searches for information

Modules: Information Behavior Models and Information Literacy

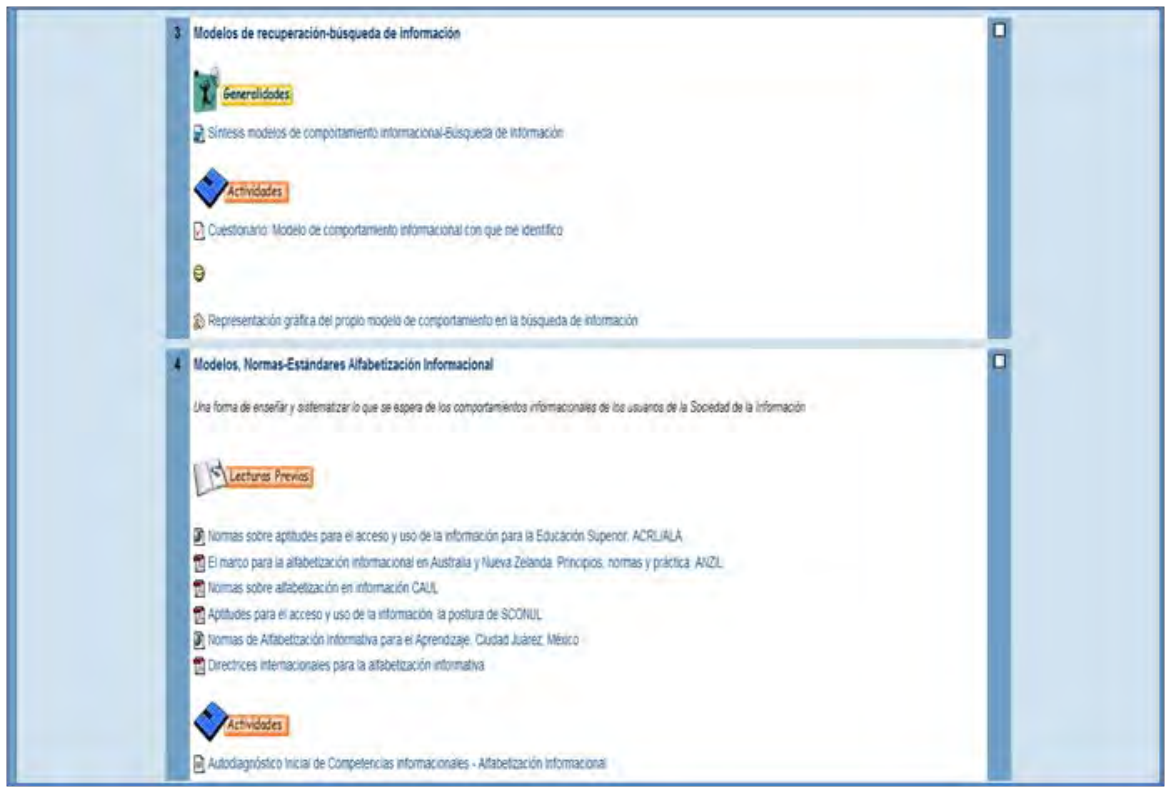

Outcomes and assessment of students in these courses (Qualitative surveys and COLLES's Moodle tool)

All these courses include continuous formative and summative assessment in order to evaluate both the processes and the results. This assessment in turn has focused both on course, where information search and retrieval is a key issue, and e-learning skills for active learning, where critical thinking and troubleshooting skills are acquired that students need in order to interact with content and teaching activities from the constructivist perspective.

The formative assessment issues are of a qualitative nature, highlighting learning activities: "Searching for a topic of personal interest," "Searching for a topic of professional interest," "Benchmarking for a proposed information service," "Identification of own information behavior model from the Information Behavior Models established by the scientific community." 
In these learning activities concept maps and blogs play a key role as tools to capture and disseminate assimilated knowledge, and generate new information and knowledge in addition to questionnaires asking about previous knowledge and experience, and self-assessment of acquired skills.

Figure 8. Example of a concept map created by a student within an ICT cluster-ISLIS course

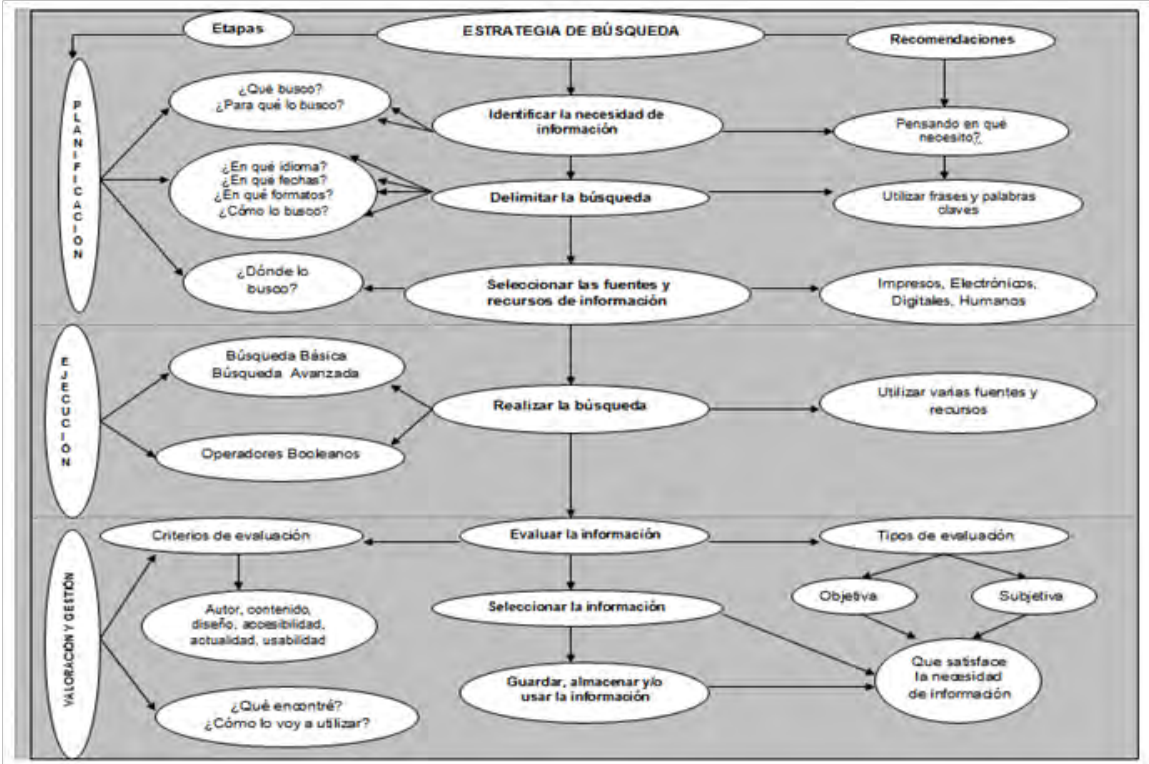

Figure 9. Example of a blog created and managed by a student within an ICT cluster-ISLIS course

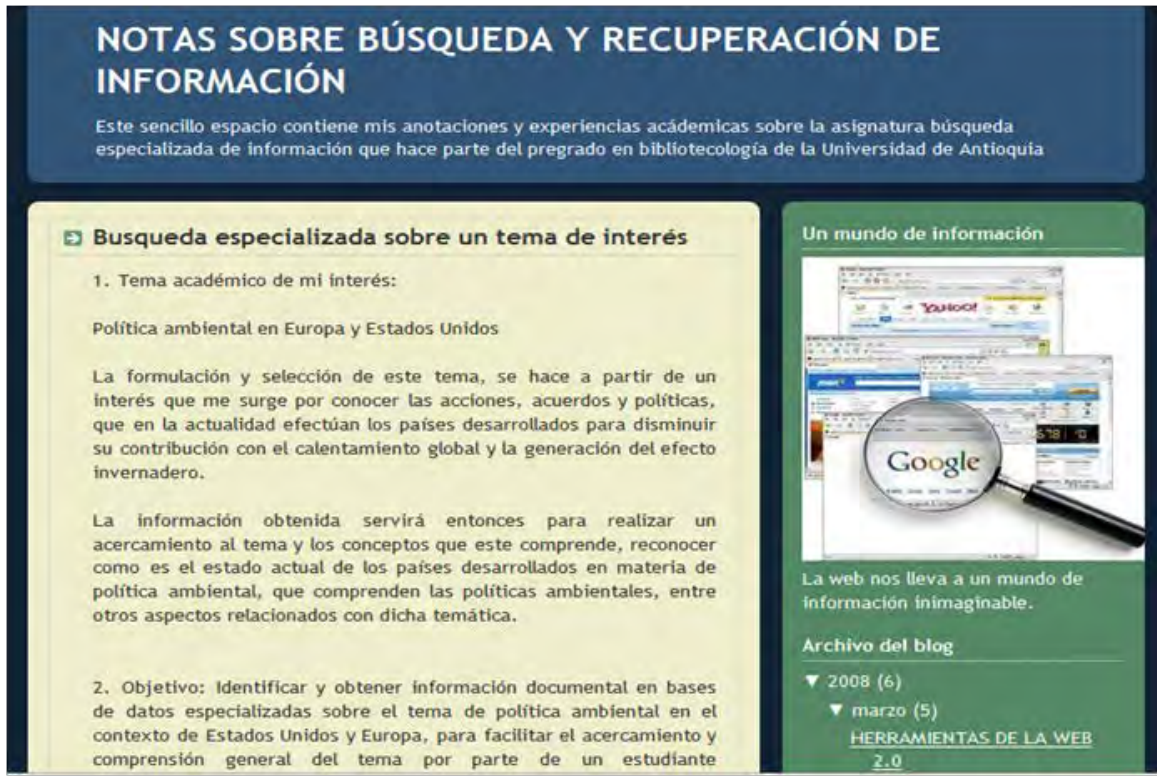


In terms of summative assessment of the educational contents of the courses in these two years, we have achieved the following results (Table 2):

Table 2. Results of summative quantitative assessment of ICT cluster-ISLIS courses applied by the Teaching Vice-Rector at the $U$ of A

\begin{tabular}{|l|c|c|c|c|c|}
\hline & $\begin{array}{c}5 \\
\text { Excellent }\end{array}$ & $\begin{array}{c}4 \\
\text { Good }\end{array}$ & $\begin{array}{c}3 \\
\text { Acceptable }\end{array}$ & $\begin{array}{c}\text { 2 } \\
\text { Poor }\end{array}$ & $\begin{array}{c}\text { 1 } \\
\text { Bad }\end{array}$ \\
\hline $\begin{array}{l}\text { Importance of the course } \\
\text { within the curriculum }\end{array}$ & $74 \%$ & $20 \%$ & $6 \%$ & & \\
\hline $\begin{array}{l}\text { Achievement of the goals } \\
\text { set in the course or curricu- } \\
\text { lar activity }\end{array}$ & $40 \%$ & $47 \%$ & $13 \%$ & & \\
\hline $\begin{array}{l}\text { Interest and currency of the } \\
\text { contents course or curricu- } \\
\text { lar activities }\end{array}$ & $74 \%$ & $20 \%$ & $6 \%$ & & \\
\hline $\begin{array}{l}\text { Use of teaching resources } \\
\text { Production tests and }\end{array}$ & $68 \%$ & $26 \%$ & $6 \%$ & & \\
\hline quizzes & $61 \%$ & $33 \%$ & $6 \%$ & & \\
\hline
\end{tabular}

Table 2. Results of summative quantitative assessment of ICT cluster-ISLIS courses applied by the Teaching Vice-Rector at the $U$ of $A$

Specifically considering the mediated learning by Moodle platform (Constructivist On-Line Learning Environment Survey - COLLES ${ }^{9}$ ), we have achieved the following results on average:

Figure 10. Integrated Results of COLLES questionnaire. ICT cluster-ISLIS courses

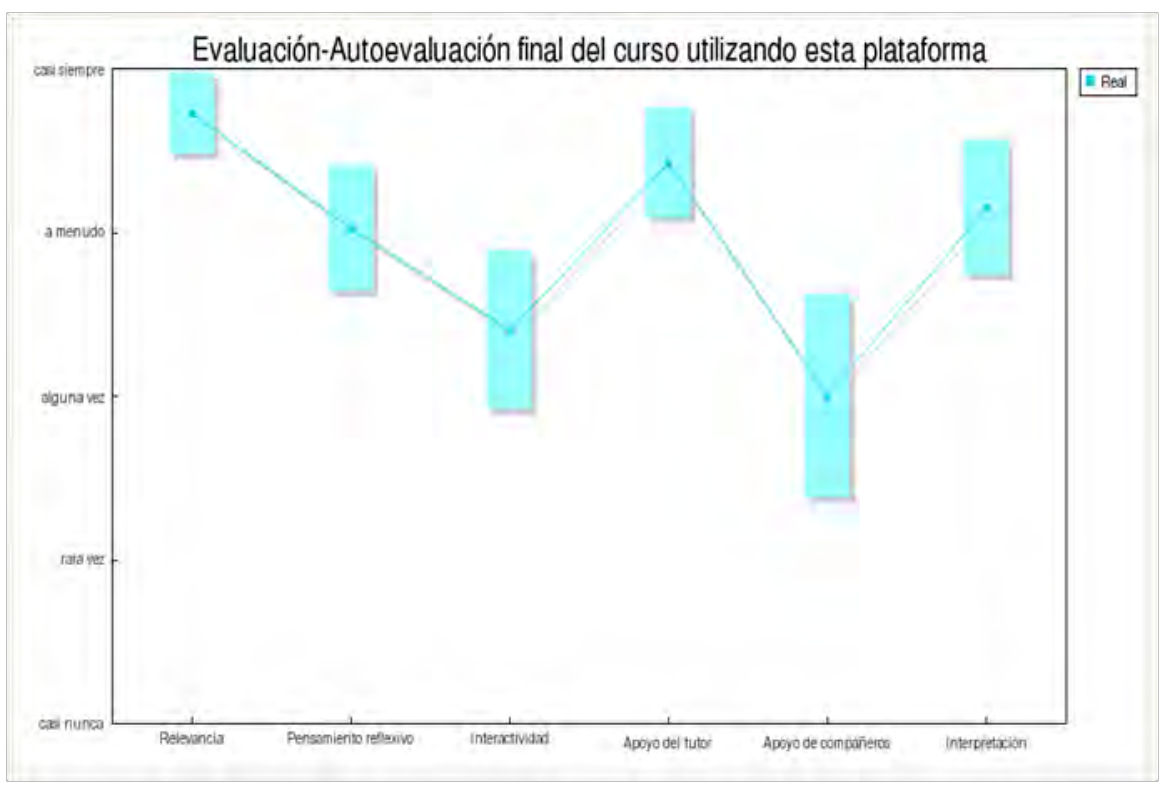

These results show that from the students' perspective, the courses have a total relevance (relevancia), thus demonstrating the importance and pertinence of curriculum changes that result in the current incorporation and development in librarian training of the ISLIS-U of A.
In turn the didactic process has allowed more reflective thinking and higher levels of discipline performance, through course content and learning activities such as the facilitator's support and interactivity that involve virtual learning environments. 
However, one aspect that has necessitated the reassessment of course development is other students' support in the learning process. This aspect demands a motivational process from teachers, to provide a way to gradually increase interaction and participation. Perspectives and overall experiences about university teaching in LIS can be changed from one where students are passive learners and teachers are the ones with the real knowledge ("the only one who knows") to a more collaborative education where everybody can participate and learn from everyone else. This is the challenge brought by the improvement process.

\section{Conclusions and Perspectives}

- For the Interamerican School of Library and Information Science (ISLIS) and the University of Antioquia (U of A):

Considering the work done by the ICT clusterISLIS in these courses and their positive assessment, as well as students' recommendations and teachers' feedback, the ICT cluster has the following views about these and other courses, to enhance skills for the search and retrieval of information, using the Moodle platform:

o All students of the ISLIS before graduating will have engaged in at least six courses (four mandatory and two electives) within the ICT cluster, enabling them to acquire the knowledge, skills and attitudes (competencies) that involve the contents of this cluster (direct dynamics) as well as other competencies: e-learning, etc. (dynamic indirect)

o Faced with the clear predominance of the English language as a tool to access more current content, it is necessary to include more course content in this language, which means the entire ISLIS curriculum must evaluate the English reading competency requirement, which is currently a requirement for graduation by the University's general policy. This should be a requirement before the fourth semester, based on the autonomy and specific knowledge involving LIS

o Clear institutional policy must be generated regarding se and access to particular tools and technological services for current and future perspectives on Web 2.0, 3.0, and others

- For training in information competencies of information science students in Latin America.

Each context of LIS instruction in Latin America carries different implications for the trajectory of the programs, curriculum guidelines, teachers' education levels, students' demographic and psychographic characteristics, and locative, technological and financial resources. However, the ISLIS-U of A experiences in the training performed in this cluster provide some common perspectives and conclusions for different library and information schools.

o There is a need to include courses in the curriculum relating both theoretical and applied developments involving Information Behavior Models, little taken into account in current related studies [21] and considered as key issues to train future librarians to be information literate and trainers in information literacy as well.

o The new educational developments imply building skills, not just bidirectional training for the acquisition of information literacy, as indicated in the previous section, but also the acquisition of elearning competencies to enable collaborative and continuous learning. As a result, the use of learning management systems (LMS) like Moodle enables instructors to support students' achievement of those competencies. For LIS education it is crucial to exchange experiences and learned lessons within the Latin American, North American and European contexts driven by the permanent need for benchmarking and assessment processes involved in librarian training to meet society's demands.

o Finally, training in information competencies is correlated with competencies of e-learning from today's perspective of library science students, as future trainers in information literacy using 
virtual learning platforms. Thus training must be a process included gradually throughout the whole curriculum, step by step and in a scalable manner, sequentially, relating these skills to other disciplinary developments studied semester after semester in the career. By undertaking this process, students can achieve "Lifelong Learning" after graduation, as long as several courses are incorporated at different levels and with diverse degrees of depth. This is a challenge to current LIS curriculum which the ISLIS-U of A is trying to meet, and wants to share with other local Schools and Faculties. ISLIS-U of A hopes, by sharing this, to learn from other experiences to help improve the curriculum and the cluster as well.

\section{References}

[1]. Rowlands, I. et al. (2008). The Google generation: the information behaviour of the researcher in the future. Aslib Proceedings, 60(4), 290-310.

[2]. Leu, D.J., Jr. (2000). Literacy and technology: Deictic consequences for literacy education in an information age. In M.L. Kamil, P. Mosenthal, P.D. Pearson, \& R. Barr (Eds.), Handbook of reading research (Vol. III, pp. 743-770). Mahwah, NJ: Erlbaum.

[3]. Jenkins, H. (2006). Confronting the Challenges of Participatory Culture: Media Education for the 21st Century. MacArthur Foundation

[4]. Huijser, H. (2008). Exploring the Educational Potential of Social Networking Sites: The Fine Line between Exploiting Opportunities and Unwelcome Imposition.Studies in Learning, Evaluation, Innovation and Development, 5 (3).

[5]. Tien, F. y Fu, T.(2006). The correlates of the digital divide and their impact on college student learning. Computers \& Education. doi:10.1016/j.compedu.2006.07.005

[6]. DuMont, R. R. (2002). Distance learning: A systems view (an assessment and review of the literature). Kent, $\mathrm{OH}$ : Kent State University. Retrieved March 30, 2003, from http://www.lib.montana.edu/ alivy/dist.html\#Evaluation Accessed 11 August 2010.
[7]. Haddad, W. D. (2001) E-Learning beyond the workplace. TechKnowLogia, 3(3)

http://www.techknowlogia.org/TKL active pages $2 /$ CurrentArticles/main.asp?IssueNumber=11\&FileType $=$ PDF\&Article ID=265 Accessed 11 August 2010.

[8]. Koper, R. (2005) Chapter 1. An introduction to learning design. In R. Koper \& C. Tattersall (Eds.) Learning design (pp. 3-20). Berlin: Springer-Verlag.

[9]. Berggren, A., et al. (2005) Practical and pedagogical issues for teacher adoption of IMS Learning Design Standards in Moodle LMS. Journal of Interactive Media in Education (2).

[10]. Zapata, D. (2002). Contextualización de la enseñanza virtual en la educación superior. Instituto Colombiano para el Fomento de la Educación Superior. Retrieved.

http://acreditacion.udistrital.edu.co /documento/pub ext/ICFES/ensenanza_virtual.pdf Accessed 11 August 2010.

[11]. Castaño-Muñoz, W. \& Uribe-Tirado, A. (2008). La formación en competencias tecnológicas e informacionales de futuros bibliotecólogos. X Congreso Nacional de Bibliotecología y Ciencias de la Información, Bogotá (Colombia), 5-7 November 2008.

[12]. Uribe-Tirado, A. (2006). Los bibliotecólogos colombianos y la adquisición de competencias. Énfasis y tendencias en la actual formación en Tecnologías de la Información y la Comunicación. Revista Interamericana de Bibliotecología, 30(1), 135-166.

[13]. Uribe-Tirado, A. (2008). Diseño, implementación y evaluación de una propuesta formativa en alfabetización informacional mediante un ambiente virtual de aprendizaje a nivel universitario: caso Escuela Interamericana de Bibliotecología, Universidad de Antioquía.

http://eprints.rclis.org/15301/9/7-8-9.pdf Accessed 22 July 2009.

[14]. Uribe-Tirado, A. et al (2008). e-Book: Acceso, conocimiento y uso de Internet en la universidad. Modelo de diagnóstico y caracterización: Caso Universidad de Antioquia., Universidad de Antioquia (Colombia). http://eprints.rclis.org/ 15285/ Accessed 22 July 2009.

[15]. Escuela Interamericana de Bibliotecología - EIB (2003). Plan Educativo Institucional PEI.

Education Libraries, Volume 34, Number 1, Summer 2011 
http://bibliotecologia.udea.edu.co/ comunicaciones/PEI.\%20 Definitivo \%202003.doc Accessed 10 July 2009.

[16]. Corrall, S. (2005). Developing models of professional competent to enhance employability in the network world. En: Preparing for new roles in libraries. München: IFLA Publications.

[17]. Eskins, R., \& Craven, J. (2008). Design for all in the Library and Information Science curriculum. In J. Craven, ed. Web accessibility: practical advice for the library and information professional (pp. 127-144). London: Facet Publishing,

[18]. Hong, X. (2003). Information technology courses and their relationship to faculty in different professional ranks in library and information science programs. Library \& Information Science Research, 25, 207-222.

[19]. Karisiddappa, C. R. (2004) Plan de estudios en biblioteconomía y documentación en los países en vías de desarrollo. 70th IFLA General Conference and Council www.ifla.org/IV/ifla70/papers/062s transKarisiddappa.pdf Accessed 22 July 2009.

[20]. Lorring, L. (2004). Behind the curriculum of library and information studies - Models for didactical curriculum reflections. 70th IFLA General Conference and Council www.ifla.org/IV/ifla70/papers/064eLorring.pdf Accessed 22 July 2009.

[21]. Guerra Pérez, Y., \& Martí Lahera, Y. (2010). La Alfabetización Informacional en la formación pre y posgradual de bibliotecarios. Breve mirada desde el análisis documental. Congreso INFO 2010-Cuba. Panel Alfabetización Informacional. http://www.congresoinfo.cu/ UserFiles/

File/Info\%202010/Trabajos/Guerra\%20P\%C3\%A9rez, $\% 20$ Yosvany INFO \%202010.doc Accessed 1 October 2010.

\section{Endnotes}

http://www.sla.org/content/SLA/professional/meaning/comp etency.cfm

${ }^{2}$ http://www.certidoc.net/es1/euref1-espanol.pdf

${ }^{3}$ http://www.documentalistaenredado.net/contenido/tit_bibli o.pdf

${ }^{4}$ http://biblis.db.dk/Archimages/423.12.05.PDF

5 This guest access is recommended by the Technology Integration Program, particularly as the $U$ of A subscribes to the National Repository of Learning Objects, but the final decision to enable this option or not is left to the teachers responsible for each course.

${ }^{6}$ To see: Synthesis information behavior models (more 20 models translate to Spanish)

http://formacionbiblioteca.udea.edu.co/moodle/mod/resource /view.php?id=4651

${ }^{7}$ To see: Self-evaluation information competencies Information Literacy Standards

http://formacionbiblioteca.udea.edu.co/moodle/mod/resource /view.php?id=5635

${ }^{8}$ See full reports in Chapter 9 of the research: Design, implementation and evaluation of an information literacy proposal through a virtual learning environment at the university level: Interamerican School of Library and Information Science at the University of Antioquia [9].

${ }^{9}$ http://surveylearning.moodle.com/colles/

Alejandro Uribe Tirado

auribe@,bibliotecologia.udea.edu.co

Wilson Castaño Muñoz

wilsoncastano@bibliotecologia.udea.edu.co

Professors - Researchers

Interamerican School of Library and Information

Science at the University of Antioquia (MedellínColombia) 